\title{
Willingness to Pay for Conservation in Gunung Gading National Park
}

\author{
Thalany Kamri \\ Universiti Teknologi MARA, Sarawak, Malaysia \\ thalany@sarawak.uitm.edu.my
}

\begin{abstract}
An open-ended contingent valuation survey was conducted involving local and international visitors to estimate the environmental economics of Gunung Gading National Park. This was to elicit the willingness to pay for its conservation. Using a random survey, the average willingness to pay was RM16.14 for international visitors per visit and RM7.38 per local visitor per visit for conservation. The willingness to pay was strongly influenced by gender, education and income. This study demonstrated that contingent valuation method can be a useful tool to guide decision makers regarding policy purposes and natural resources management of protected area in developing countries.
\end{abstract}

Keywords: contingent valuation; open-ended; protected areas; conservation

eISSN 2398-4279 @ 2018. The Authors. Published for AMER ABRA cE-Bs by e-International Publishing House, Ltd., UK. This is an open-access article under the CC BY-NC-ND license (http://creativecommons.org/licenses/bync-nd/4.0/). Peer-review under responsibility of AMER (Association of Malaysian Environment-Behaviour Researchers), ABRA (Association of Behavioural Researchers on Asians) and cE-Bs (Centre for EnvironmentBehaviour Studies), Faculty of Architecture, Planning \& Surveying, Universiti Teknologi MARA, Malaysia.

DOI: https://doi.org/10.21834/ajqol.v3i9.91 


\subsection{Introduction}

Forest is an example of the area which holds uncountable biodiversity on the planet. However, these areas are exposed to threats that are mainly caused by human activities where the world population is rising and the global economic expands. The threats include human settlement, infrastructure development, tourism, recreation and resource extraction (Chape et al., 2008). The annual rate of forest loss in Southeast Asia was about 898,000 hectares (FAO, 2011). Asian countries especially Indonesia, Myanmar and also Malaysia are experiencing a reduction of forest at risking rate, where even if the forest are to survive, they are often logged or degraded (Chape et al., 2008).

The aim of this paper was to assess the economic value that local and international visitors placed for the purpose of conservation. Specifically, this survey elicited the amount respondents were willing to pay to conserve the Gunung Gading National Park (GGNP) which is home for the largest flower, Rafflesia, in Sarawak, Malaysia. This survey also investigated the variables which might be used to model this economic valuation.

\subsection{Description of the Area}

Sarawak is the largest state in Malaysia with a total area of $124,450 \mathrm{~km}^{2}$ or 12.445 million hectares that are $37 \%$ of Malaysia area. The state is situated on the island of Borneo which is the third largest island in the world after Greenland and New Guinea (Rautner et al., 2005). Sarawak is a small developing tourism destination in South East Asia. In 2010, of the total 24.6 million visitor arrivals to Malaysia, Sarawak has accounted for $13.3 \%$ (3.27 million) of visitors. Visitors to Sarawak are attracted to its rich and unique biodiversity as Malaysia ranked $12^{\text {th }}$ in the world according to the National Biodiversity Index (NBI) (UNDP and FRIM, 2008).

GGNP is situated in the Lundu district of Sarawak and was gazetted as a park in 1st August 1983 with a total area of 4,196 hectares. It was opened to the public in 1994, and visitors can enjoy its beautiful waterfalls and challenging treks, even a summit that visitors can climb. This park was primarily accommodated to provide a conservation zone for the protection of the biggest flower found on the planet which is the Rafflesia. The species of Rafflesia found here is called the Rafflesia Tuan-Mudae (Beloved Prince).

\subsection{Methodology}

The 2012 study was based on a random survey of 270 respondents, consisting of 170 (63\%) local visitors and $100(37 \%)$ international visitors. The face-to-face interviews were conducted over a period of two months (April and May 2012), corresponding with the blooming season of the Rafflesia Respondents were briefed about the purpose of interview and questionnaire. The general information and environmental issues of GGNP were introduced. Respondents were assured that all the responses were to be used for research purposes and confidentially would be maintained. The interviews were conducted only to adult visitors with income as they were considered to be realistic in making the decision on valuation for the WTP of conservation in GGNP subject to their budget constraint.

The contingent valuation method (CVM) was employed for this study. This method has 
been extensively used to estimate the value of non-marketed goods and services through interviews using questionnaire survey (Dall'Aste Brandolini and Lamberti, 2003). CVM is a standardize used method for determining WTP for conservation (Mitchell and Carson, 1989). This method elicits respondent's preferences for non-marketed goods and services by asking them how much they would be willing to pay to acquire improvement or to avoid negative aspect in them (Mitchell and Carson, 1989).

This study used open-ended questions to elicit respondents' WTP. Open ended elicitation method (Andersson, 2007; Togridou et al., 2006) is the most straightforward where the respondents will be asked directly on their maximum WTP. The other advantage is that it is easy to calculate mean and median of WTP. Togridou et al. (2006) used this format for valuing WTP among visitors to the national park, whilst Jabarin and Damhoureyeh (2006) estimated Jordanian's WTP for the improvement of their national park. Andersson (2007), on the other hand, applied this format to value individual's WTP for trip access to the national park. Hanemann (1994) mentioned that open-ended questionnaires allow the respondent to answer without pressure, and they have the flexibility in responding. Hence this situation may avoid the issues of starting point bias and hypothetical bias.

\subsection{Survey design}

The questionnaire consisted of four sections: Section A, B, C and D. In Section A, visitors were asked about their personal backgrounds. Section B covered on respondents' expenditure, activities, park guide service and also satisfaction of paying such fee to the activities that they had gone through. The most crucial feedback required was in Section C. This was on their willingness to pay by a certain amount of conservation fee. For this, they were required to answer either "Yes" or "No". Next, question was to discover the respondent's maximum WTP for conservation fee. The final Section $D$ was simply asking them whether to visit the park in the future. The data derived from the questionnaires were analyzed by using SPSS packages. Forms of data analysis that will be performed are descriptive analysis, coefficient correlation test and multiple linear regression analysis.

\subsection{Findings and Analysis}

\subsection{Visitors' profile}

Table 1 displays the summary of visitors' profiles. By gender, the majority of visitors were male $(60.4 \%)$. More than half were single $(58.8 \%)$. Most of the visitors were between 20 to 29 years old $(44.4 \%)$, followed by the age group 30 to 39 years old $(22.2 \%)$. More than half of the visitors were Malaysian (63\%) while the rest were International visitors (37\%). In terms of educational background, $29.3 \%$ had attained first degrees, $26 \%$ of the visitors had completed secondary education and $21.1 \%$ of the visitors had diploma. Most visitors were private employee (33.7\%). The second and third highest groups of visitors were selfemployee $(23 \%)$ and government servant $(20.7 \%)$ respectively. In terms of income, majority of visitors earned an income of more than RM4000 (26.7\%). This was followed by an income group of between RM1000-RM1999 which was $23.7 \%$. Majority of the visitors (85.6\%) were 
not a member to any of the environmental organisation. The remaining $14.4 \%$ were a member of organisation such as Persatuan Perlindungan Alam Sekitar Malaysia (PPASM), Malaysia Nature Society (MNS), Pejasa, WWF-Malaysia, Sierra Club and Green Peace.

Table 1: Visitor's profiles

\begin{tabular}{|c|c|c|}
\hline Characteristics & Percentage (\%) & $n$ \\
\hline \multicolumn{3}{|l|}{ Gender } \\
\hline Male & 60.4 & 163 \\
\hline Female & 39.6 & 107 \\
\hline \multicolumn{3}{|l|}{ Marital status } \\
\hline Single & 58.5 & 158 \\
\hline Married & 41.5 & 112 \\
\hline \multicolumn{3}{|l|}{ Nationality } \\
\hline Malaysian & 44.4 & 80 \\
\hline International & 55.6 & 100 \\
\hline \multicolumn{3}{|l|}{ Age } \\
\hline $13-19$ & 10.0 & 27 \\
\hline $20-29$ & 44.4 & 120 \\
\hline $30-39$ & 22.2 & 60 \\
\hline $40-49$ & 9.3 & 25 \\
\hline$>50$ & 14.1 & 38 \\
\hline \multicolumn{3}{|l|}{ Education Level } \\
\hline Master Degree/PhD & 16.3 & 44 \\
\hline Bachelor Degree & 29.3 & 79 \\
\hline Diploma & 21.1 & 57 \\
\hline Secondary School & 26.7 & 72 \\
\hline Primary School & 6.7 & 18 \\
\hline \multicolumn{3}{|l|}{ Occupation } \\
\hline Self employed & 23 & 62 \\
\hline Government servant & 20.7 & 56 \\
\hline Student & 17.8 & 48 \\
\hline Private employee & 33.7 & 91 \\
\hline Retired & 4.8 & 13 \\
\hline \multicolumn{3}{|l|}{ Monthly Income } \\
\hline$<$ RM1000 & 21.1 & 57 \\
\hline RM1000 - RM1999 & 23.7 & 64 \\
\hline RM2000 - RM2999 & 17.4 & 47 \\
\hline RM3000 - RM3999 & 11.1 & 30 \\
\hline$>$ RM4000 & 26.7 & 72 \\
\hline \multicolumn{3}{|c|}{ Members of any environmental organisation } \\
\hline Yes & 14.4 & 39 \\
\hline No & 85.6 & 231 \\
\hline
\end{tabular}

\subsection{Characteristics of visits}

Table 2 outlines the characteristics of visits. The result shows that more than half of visitors in this study $(78.5 \%)$ first time visited this national park while the others $(21.5 \%)$ visited more frequently, and they felt this national park as the second place for them to do more social activities with family and friends. In terms of expenditure, $70.4 \%$ of visitors spent less than RM50 to visit GGNP where mostly came to this park for a day trip. $12.6 \%$ of visitors spent more than RM100, as they needed to stay longer and need more time to explore GGNP. 
Most of the visitors (38.1\%) visited this park for hiking, jungle tracking and nature walk, followed by relaxing, sightseeing and picnic $(28.1 \%)$. Majority of them brought along their family member to visit this park. Next, about $(27.8 \%)$ of visitors came to this national park just to see the Rafflesia. Especially, for those who had never seen the flowers.

Table 2: Characteristics of visits

\begin{tabular}{lll}
\hline Characteristics & Percentage (\%) & $\mathbf{n}$ \\
\hline First time visit & 78.5 & 212 \\
Yes & 21.5 & 58 \\
No & & \\
Gross spending amount & 70.4 & 190 \\
<RM50 & 17.0 & 46 \\
RM50 - RM100 & 12.6 & 34 \\
>RM100 & & \\
Activities by visitors & 38.2 & 103 \\
Hiking/jungle trekking/nature walk & 6.0 & 16 \\
Wildlife photo taking & 28.2 & 76 \\
Relaxing/sightseeing/picnic & 27.8 & 75 \\
Others & & \\
Need park guide service & 64.4 & 174 \\
Yes & 35.6 & 96 \\
No & & \\
Worth to pay the entrance fee & 95.2 & 257 \\
Yes & 4.8 & 13 \\
No & & \\
Day trip & 76.7 & 207 \\
Yes & 23.3 & 63 \\
No & & \\
\hline
\end{tabular}

More than half of visitors in this study (64.4\%) prefer to seek guidance of park guides. The remaining $(35.6 \%)$ need privacy and able to explore the park on their own. $95.2 \%$ of the visitors were expressing that it was worth to pay the entrance fee to the activities that they had experienced. Finally, more than half of visitors in this study $(76.7 \%)$ prefer to visit as a day trip only. While $23.3 \%$ of them prefer to stay on the average of 2 nights.

Visitors' WTP

On the overall, all visitors pointed out their WTP for conservation fee in different level of price. There are few reasons why the visitors wanting to pay some amount to conserve this park. The payment should be charged to protect the environment. It is necessary for people to be aware and care about the protection of natural resources. Table 3 shows the visitors' mean WTP in response to the price of conservation fee. The study found that visitors' mean WTP for conservation fee was RM10.63. The findings also revealed that international visitors were willing to pay RM16.14 for conservation fee compared to local visitors at only RM 7.38. From these values of visitors' surplus or the WTP for conservation of GGNP, the additional net benefit of the park can be computed as shown in Table 4. The estimated additional revenue from conservation fee is the additional benefit that GGNP would gain besides the current entrance fee charges. At the time of this survey, the entrance fee charge was RM10 per entry per visitor. 
Table 3: Visitors' WTP

\begin{tabular}{lll}
\hline Respondents & Conservation fee (RM) & $\mathbf{n}$ \\
\hline Visitors & 10.63 & 270 \\
Local visitors & 7.38 & 170 \\
International visitors & 16.14 & 100 \\
\hline
\end{tabular}

Table 4: Estimated revenue from conservation fee

\begin{tabular}{ll}
\hline Year & $\begin{array}{l}\text { Estimated additional revenue } \\
\text { (RM) }\end{array}$ \\
\hline 2011 & $289,252.93$ \\
2012 & $301,977.04$ \\
\hline
\end{tabular}

An analysis of the WTP provided an opportunity to study the content and context validity of this survey. An ordinary least squares regression was used to analyse WTP. The regression revealed that the list of variables attained the expected signs as presented in Table 5. As expected, an increase in the monthly gross income would increase the WTP: $1 \%$ increase in visitors' income would increase WTP by an average of $0.742 \%$. The positive sign of education means that an increase in number of years of education would increase their WTP. More specifically, $1 \%$ increase in years of education; it would increase WTP by an average of $0.953 \%$. Income and education are among the most applied variable to describe the profile of any research sample. This model has discovered that these two variables have a significant relationship with respondents' WTP. It was found that an increase in income will result in a relatively low increase in WTP. On the other hand, an increase in education level relates to a higher increase in WTP. Therefore, income is important. However, its effect is usually short-term. When we asked about income, visitors have to consider other expenses such as accommodation, food, transportation cost and others. The effect of education on a visitor is lasting. As such, it will increase their knowledge and may eventually have an impact on the thinking of a rational visitor. This normally will shape the visitor's perception and attitude in a more matured manner. Since what they learn is embedded in them as individual, the effect of education on their behaviour is usually quite strong, especially, if it is consistent with their perception such as the WTP. From the study, there is a possibility that the education of respondents had a strong contribution to respondents WTP. On the other hand, incomes of the respondents were not so high as to provide significant effects on the WTP. In this study, both income and educational level were found to be significant variables in influencing the WTP.

This study also found that nationality of visitors had an insignificant effect towards WTP. Local visitors are lesser in their WTP for conservation fee compared to international visitors. On the other hand, marital status and gender of visitors were found to be significant in influencing WTP. Married male visitors are willing to pay more for conservation fee. The reason was they want their family members experiencing what they were enjoying such as scenic beauty of the national park, wildlife observation and other activities. In other words, it can be noted that they were more willing to pay to conserve this virgin forest swamp forest in GGNP for future generation. 
Table 5: OLS regression estimates

\begin{tabular}{llll}
\hline Variable & Coefficient & Std error & t-statistic \\
\hline Constant & $13.018^{*}$ & 2.694 & 4.833 \\
Income & $0.742^{* *}$ & 0.370 & 2.007 \\
Age & 0.171 & 0.327 & 0.521 \\
Nationality & $-5.119^{*}$ & 1.054 & -4.855 \\
Gender & $1.762^{*}$ & 0.589 & 2.991 \\
Marital status & $1.671^{* *}$ & 0.781 & 2.139 \\
Education & $0.953^{* *}$ & 0.434 & 2.194 \\
\hline$R^{2}$ & 0.492 & & \\
Adjusted $R^{2}$ & 0.481 & & \\
F stats & 42.490 & & \\
d.f. & 269 & denotes statistically significant at 99\% confidence level \\
\hline \multicolumn{4}{c}{ denotes statistically significant at 95\% confidence level }
\end{tabular}

\subsection{Discussion}

The number of visitors to Sarawak national parks is increasing at an increasing rate each year. Compared to other national parks, the rate of visitors coming to GGNP increasing at about the same rate. This was because visitors seldom return for a second time to the same area. Therefore, the WTP stated by the majority of visitors (locals) was for that particular Rafflesia species. On the other hand, the international visitors stated they would want to contribute to the organisation and environmental development in the host country. This study also revealed that, visitors of GGNP did not depend upon the benefits they would get in conserving the park. They mentioned that their WTP was to keep the park beautiful, unexploited landscape and diversity of flora and fauna that belong to this area. These are among the push factors that influence visitors to visit a national park (Noralizawati and Noriah, 2010).

The demand for ecotourism in Sarawak by international and local visitors has also been increasing each year. Walsh (1986) provided an outline of the effect of price elasticity of demand for various recreational activities. Price elasticity of demand on recreational activity is generally low when the proportion of income spent on it is low. This could be an indication of the income effect at the national level. As visitors' income level grows, the income elasticity may improve for environmental goods and services. The participation increased with higher level of education and increasing income. Therefore, the magnitude of economic problems restricted the local visitors in contribution more to conservation fee as their income are very much lower than international visitors. Therefore, conservation fee to GGNP were given low priority by most of the local visitors, that is, except for a few high income group among them. This was because they felt that they have contributed to environmental development when paying tax to the government 


\subsection{Conclusion}

Environmental valuation studies have been carried out and applied in developing countries. This demonstrates that the CVM is a promising approach to elicit WTP as they include a wide range of societal concerns about environmental management. However, the WTP is lacking in the inclusion of non-monetary contribution. From this study, the WTP for GGNP is positive. The response from local visitors as well as international visitors served as a good indicator of the role that visitors can contribute for the purpose of the national park conservation. Mean WTP per visitor per visit was higher for international visitors compared to local visitors. This inferred to the attributes of higher income and general awareness that international visitors have. The management authority could also implement education programmes that can increase the level of awareness among visitors. It is believed that visitors, who have the right information on park conservation, are more positive in their perception and decision especially those involving payment. In addition, goods and services should contain some educational elements, contributing to knowledge and experience of the visitors. It can be agreed that management plans supported by research such as this will be more credible. The management can use this to justify any changes such as increase in fees to the authorities. These findings can assist SFC to design the most appropriate fee structure, both for the visitors and to meet its own objectives. Therefore, the result of this study using CVM could be a useful tool in providing relevant information for decision makers and policy purposes in biodiversity and protected area management. Information on issues such as factors influenced visitors WTP and socio-demographic and economic characteristics of visitors will provide a guideline and information for Sarawak Forestry Corporation (SFC). This will also contribute to the long-term sustainable development of GGNP specifically and other national parks in Sarawak generally.

It is important to remember that task and responsibility of protecting and preserving nature resources and its wildlife such as GGNP is not solely appointed on the government or legal authority involved, it is a matter of cooperation among the particular authority and the public. Besides, with this, not only we help our world by preserving and protecting the natural resources but also our children and the future generation.

\section{Acknowledgement}

The author would like to thank the SFC and Sarawak Forest Department in providing necessary information for the purpose of this study. In addition, the author is grateful to both Assoc. Prof. Dr. Alias Radam and Dr. Zaiton Samdin of UPM for many meaningful discussions on this topic.

\section{References}

Andersson. (2007). The recreational cost of coral bleaching - A state and revealed preference study of international tourists. Ecological Economics, 62 (3-4), 704-715. 
CBD. (1992). Convention of Biological Diversity. Brazil: United Nations.

Chape, S., Spalding, M., \& Jenkins, M. (2008). The World's Protected Areas. Berkeley, USA: UNEP World Conservation Monitoring Centre, University of California Press.

Dall'Aste Brandolini, S. M., \& Lamberti, A. (2003). Economics and social valuation of the defense system of Venice and its lagoon. In E. Ozhan (Ed.), Sixth International Conference on the Mediteranean Coastal Environment (pp. 307-318). Italy: MEDCOAST.

FAO. (2011). State of the World's Forests 2011. Rome: Food and Agriculture Organization of the United Nations.

Hanemann, W. M. (1994). Valuing the environment through contingent valuation. Journal of Economic Perspectives , $8(4), 19-43$

IUCN. (1994). Guidelines for Protected Areas Management Categories. Gland, Switzerland: IUCN.

Jabarin, A. S., \& Damhoureyeh, S. A. (2006). Estimating the recreational benefits okf Dibeen National Park in Jourdan using contingent valuation and travel cost methods. Pakistan Journal of Biological Sciences , 9 (12), 21982206.

Mitchell, R. C., \& Carson, R. T. (1989). Using Surveys to Value Public Goods: The Contingent Valuation Method. Washington DC: Resources for the Future.

Morrison, M. D., Blamey, R. K., Bennett, J. W., \& Louviere, J. J. (1996). A comparison of stated preference techniques for estimating environmental values, Research Report No. 1. Canberra: School of Economics and Management, University College, The University of New South Wales.

Nagle, J. C. (2009). The effectiveness of Biodiversity Law. Journal of Land Use , 24 (2), 203-252.

Rautner, M., Hardiono, M., \& Alfred, R. J. (2005). Borneo: Treasure Island at Risk. Germany: WWF Germany, Frankfurt am Main.

Togridou, A., Hovardas, T., \& Pantis, J. D. (2006). Determinants of visitors' willingness to pay for the National Marine Park of Zakynthos, Greece. Ecological Economics , 60 (1), 308-319.

UNDP \& FRIM. (2008). Natural History Museum Malaysia: Planning and Development. (S. P. Francis, Ed.) Kuala Lumpur: United Nations Development Programme and Forest Research Institute Malaysia.

UNEP. (2010). State of Biodiversity in Asia and the Pacific. Nairobi, Kenya: United Nations Environment Programme.

Walsh, R. G. (1986). Recreation Economic Decisions: Comparing Benefits and Costs. State College, PA: Venture Publishing Inc. 